\title{
Factors Affecting Oral Communication In the EFL Classroom in Kuwait
}

A Study in the Higher Institute of Telecommunication and Navigation (HITN) in Kuwait

\section{(Jawaher Alrowayeh) \\ (An Instructor of English at Higher Institute of Telecommunication and Navigation HITN at PAAET - Kuwait)}

\begin{abstract}
This study investigates the factors that affect oral communication in the English Language classroom. The importance of this study arose from the importance of oral communication in EFL learning. Through oral communication, the language is used through a context and that indicates a successful language learning. Oral communication involves two of the learning skills which are listening (the primary channel for learning) and speaking. That is why it is considered a vital element in language learning process. From this point, the researcher has chosen to study the factors that affect oral communication in the English language classroom in Kuwait. It has been noticed, in general, a lack in this skill in English classes while there is a great emphasis on the other skills like reading and writing. In this paper, the researcher has chosen students from different grades studying in the Higher Institute of Telecommunication and Navigation (HITN) in Kuwait. A questionnaire was used as a tool to collect data. The findings of the study shows different factors that affect oral communication in the EFL classroom such as: the teachers' attitude towards students' errors, the atmosphere of the class, the students' feel of anxiety and the fear of making mistakes, the lack of using English by students in communication in
\end{abstract}

مجلة كلية التربية- جامعة عين شمس 15 () العدد الواحد والأربعون (الجزء الاول) 2017 
Factors Affecting Oral Communication In the EFL Classroom in Kuwait A Study in the Higher Institute of Telecommunication and Navigation (HITN) in Kuwait

the class and outside the class, the problem of facing difficulties in speaking English, the great concentration on grammar in the syllabus and the limited use of recording for listening exercises.

Key Words: Oral Communication - EFL classroom - HITN Kuwait 


$$
\text { ملخص الدراسة: - ماس }
$$

تهدف هذا الدراسة للتعرف على العوامل التي تؤثر على الاتصال اللفظي في فصل اللغة الإنجليزية. وتتبثق أهية هذه الدراسة من أهمية الاتصال اللفظي في

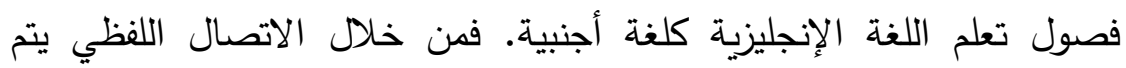
استخدام اللغة في سياق الكلام ومن خلال حوارات لفظية مما يساعد على تعلم اللغة بشكل سليم. ويتضمن الاتصال اللفظي مهارتين أساسيتين وهما مهارة الاستماع وهي تعتبر المرحلة أولى في التعلم وكذلك مهارة التحدث. لهذا يعتبر

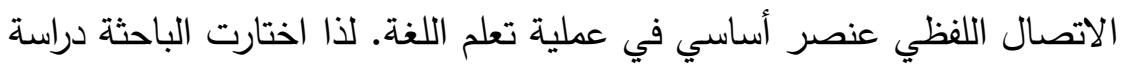
العوامل التي تؤثر على الاتصال اللفظي في فصل اللغة الإنجليزية في المعهد

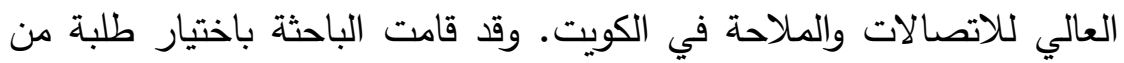

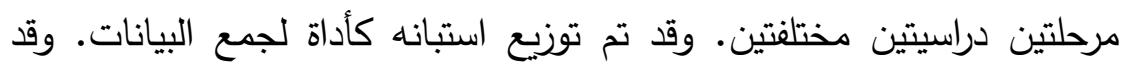
أظهرت النتائج العديد من العوامل التي تؤثر بشكل سلبي على الاتصال الفظي توني

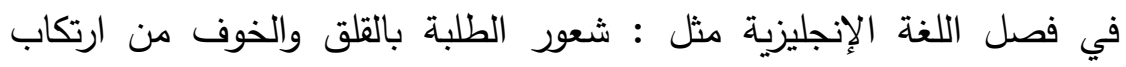
الأخطاء، وموقف المعلم اتجاه أخطاء الطلبة، والجو العام للفصل، وقلة استخدام الطلبة للغة الإنجليزية داخل وخارج الفصل، ومشكلة مواجهة الصعوبات عند الهاه التحدث اللغة الإنجليزية ، والتركيز على قواعد اللغة الإنجليزية في المناهج الدراسية ، وكذلك الاستخدام المحدود لجهاز المسجل عند ممارسة مهارة

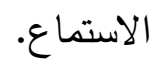


Factors Affecting Oral Communication In the EFL Classroom in Kuwait A Study

in the Higher Institute of Telecommunication and Navigation (HITN) in Kuwait

Factors Affecting Oral Communication In the EFL Classroom in Kuwait

A Study in the Higher Institute of Telecommunication and Navigation (HITN) in Kuwait

\section{(Jawaher Alrowayeh) \\ (An Instructor of English at Higher Institute of Telecommunication and Navigation HITN at PAAET - Kuwait) \\ Introduction \& Theoretical Background:}

No one denies the importance of oral communication in learning a foreign language since good communication indicates good learning. In Kuwait, English is taught as a foreign language. Therefore, the English language is not practiced outside the classroom. The only way to practice the language is only in the classroom. However, it has been noticed that students are not willing to communicate in the English classroom neither with their teacher nor with their peers. Several studies all over the world have mentioned that in most EFL classrooms, a weakness in the use of language through oral communication and interaction has been noticed.

Cortazzi \& Jin, (1996); and Tsui, (1996) stated that it has been found that many second language (SL) and foreign language (FL) students are passive in the language classroom and choose not to use the target language most of the time, especially when responding to teachers' questions and during discussions. "Making learners talk is still a challenge for teachers, as it has been frequently reported that most EFL learners are passive ,quiet, shy, reticent, and unwilling to answer" (Nazari \& Allahyar, 2012 p.18). Therefore, it was obvious that some students are good in writing and reading but they are incompetent in the speaking skill which is

$$
\text { مجلة كلية التربية- جامعة عين شمس } 18 \text { () العدد الأربعون (الجزء الرابع) } 2016
$$


considered an important and an essential part in practicing and using any language.

In her study, Shumin (1997) concluded that "due to the minimal exposure to the target language and contact with native speakers, adult EFL learners in general are relatively poor at spoken English, especially regarding fluency, control of idiomatic expressions, and understanding of cultural pragmatic."(p.2). She thinks that effective oral communication requires the ability to use the language appropriately in social interactions. Shumin stated that "Speaking a language is especially hard for foreign language learners because effective communication requires the ability to use the language appropriately in social interaction (as cited in Renandya \& Richards, 2002, p.204).

The speaking skill allows the speaker to use the language as a tool for communication. Rahman, (2010) mentioned that "speaking is a mode of communication most often used to express opinions, make arguments, offer explanations, transmit information, and make impressions upon others." (p.1). Thornbury, (2005) has mentioned that "speaking is a multi- sensory activity because it involves paralinguistic features such as eye-contact, facial expressions, body language, tempo, pauses, voice quality changes and pitch variation." (p.9).

In the classroom, speaking leads to communication and participation which is very important for effective learning. Regarding the importance of interaction, Mukkalel (1994) states that "interaction is a stimulus-response situation with some degree of verbal or non-verbal exchange that would result in positive or negative feelings in the individuals who function as the agents of the interaction".(p 104)

Generally, researches show that students often do not respond to teachers' questions and they do not volunteer

$$
\text { مجلة كلية التربية- جامعة عين شمس } 19 \text { () العدد الواحد والأربعون (الجزء الاول) } 2017
$$


Factors Affecting Oral Communication In the EFL Classroom in Kuwait A Study

in the Higher Institute of Telecommunication and Navigation (HITN) in Kuwait

answers or initiate questions. They are reluctant to participate in classroom discussion. This situation does not achieve the goals of language teaching which is encouraging learners to communicate effectively. Freiermuth \& Jarrel, (2006) have found that a lack of willingness to use the language results in ineffective interaction and language production. Therefore, "involvement and participation in classroom discussions are essential for language acquisition, the more utterances the learners offer, the better their spoken language is and vice versa." Abebe \& Deneke, 2015, (p.75).

From this discussion, the importance of oral communication appears clearly in a language learning classroom to achieve successful learning. But, what does the word "communication" mean? A lot of researchers tried to define the word "communication" since early ages. The Greek philosopher teacher Aristotle (384-322 B.C) designed a model of communication that consists of three parts: a speaker, a message, and a listener. According to Aristotle, a speaker sends a message to an audience and the audience is affected by the message received. The American political scientist and communication theorist Bwight (1978) thinks that communication means "who says what to whom in what channel with what effect." In 1955, Wilburn Schramm proposed a model of communication which was considered a comprehensive model. This model involved four stages: encoding process, selecting the right channel, encoding the message, and receiving feedback.

In more recent studies, Halliday (1978) explained that "communication is more than merely an exchange of words between parties."(p.169). It is a sociological encounter (Halliday p.139) "and through exchange of meeting in the communicative process, a social reality is created, maintained and modified (Halliday p169). Richard \& Rogers

$$
\text { مجلة كلية التربية- جامعة عين شمس } 20 \text { () العدد الأربعون (الجزء الرابع) } 2016
$$


(Jawaher Alrowayeh)

(1986) quoting La Forge (1983), declared that "oral communication is more than just a message being transmitted from a speaker to a listener; the speaker is at the same time both subject and object of his own message" (p.91).

Bizzell (1989) mentioned that a successful communication is context- dependent and therefore, embedded in its particular discourse community. Suresh (2003) defines communication as "a synonym of interchange, dialogue, sharing, interactive or communion. It is the passing of meaningful messages and the receiving of feedback." (p.1). In Britannia Encyclopedia, the word communication is defined as: a process by which information is exchanged between individuals through a common system of symbols, signs or behavior."

Based on all the above definitions, oral communication is a vital part in the learning process and it cannot be ignored. When communication is effective, both the learner and the teacher benefit. Oral communication makes the learning process easier, helps learners achieve the goals of learning, increases opportunities for expanded learning, strengthens the connection between the learner and the teacher and creates an overall positive experience.

Since oral communication is highly important in the language learning process, the researcher has decided to find out the factors that affect oral communication in the classroom and try to find the best solution to overcome these factors.

\section{Significance of the study}

Oral communication is an important factor in language learning. It is the main purpose of learning any language. It helps students to interact with others confidently. In Kuwait, there is a general weakness in the English language and especially in the speaking skill. The

مجلة كلية التربية- جامعة عين شمس 21 () العدد الواحد والأربعون (الجزء الاول) 2017 
Factors Affecting Oral Communication In the EFL Classroom in Kuwait A Study

in the Higher Institute of Telecommunication and Navigation (HITN) in Kuwait

researcher as an instructor with 25 years of experience has encountered this problem in many classes. So, it has been decided to investigate the factors that affect oral communication in the EFL classroom and try to find effective ways for successful language learning. The results of this study may be taken as the basis to manage those factors and to find out ways to enable teachers to develop the teaching approaches and strategies to encourage EFL students to communicate in the EFL classroom. This will be of great importance to teachers and learners of English.

\section{Research Problem}

The problem of weakness in the oral communication skill clearly appears in EFL classrooms. This problem was mentioned worldwide by many researchers. Kuutila (2014), Abebe \& Deneke (2014) and Rodriguez \& Barrera (2015) and many other researchers have discussed this problem in their research studies and have figured out different results.

\section{Research Questions}

In this study, the researcher will try to find out factors that affect oral communication in the EFL classroom in HITN by answering the following questions:

1) How does the teacher affect oral communication in EFL classroom?

2) How does the student affect oral communication in EFL classroom?

3) How does the syllabus affect oral communication in EFL classroom?

4) How do methods of teaching affect oral communication in EFL classroom?

5) Are there any significant differences in perception of the above factors between students regarding the following variables: gender, age, level of study and the grade in the subject of English?

$$
\text { مجلة كلية التربية- جامعة عين شمس } 22 \text { () العدد الأربعون (الجزء الرابع) } 2016
$$


(Jawaher Alrowayeh)

\section{Literature Review}

Nowadays, the English language has become dominant. In many countries, the English language is being taught as a foreign language (EFL). Therefore, a lot of issues have appeared regarding EFL teaching and oral communication in the classroom. Rodriguez \& Barrera (2015) have tried to enhance oral communication and interaction as beneficial tools that can improve the foreign language learning process in the English classes. To achieve their goals, they have used some activities based on the "Communicative Language Teaching Approach" in some schools. Rodriguez \& Barrera have reached a result that the teacher should be a model for his students in using the second language (L2) all the time and he should encourage his students to use the second language (L2) without obligating them. Moreover, teachers must give their students the opportunities to practice the language in the classroom in different activities. This recommendation agrees with what Savignoon (1991) stated that the "Communicative Language Teaching has become a term for methods and curricula that embrace both the goals and the processes of classroom learning; achieving the objectives of using the language for communication and learning, both at the same time, it offers the two opportunities in the learning process; this is not only allows students to have the advantages of a language different from their mother tongue but, also the chance to improve the communicative performance and use of the same language learned."(p.1).

Kuutila (2014) has discussed the instruction "Willingness to Communicate" (WTC) in her study. The results have shown that both teachers' behavior and their teaching methods had an impact on the participants' selfreported willingness to communicate in English in their EFL classroom. Abebe, et.al.( 2014) have concluded that students

$$
\text { مجلة كلية التربية- جامعة عين تمس } 23 \text { () العدد الواحد والأربعون (الجزء الاول) } 2017
$$


Factors Affecting Oral Communication In the EFL Classroom in Kuwait A Study

in the Higher Institute of Telecommunication and Navigation (HITN) in Kuwait

were submissive and quiet in language classrooms as a result of several reasons such as fear of losing face, their inability to understand concepts, the passive learning styles they were accustomed to, lack of preparation before coming to class, and their perceived linguistic abilities. The researchers have recommended several ways to reduce those problems and suggested to provide "a supportive learning environment that makes learners more motivated, confident and less anxious in speaking English, and gives them a higher perceptions of their abilities" (Lisa,2006).

Batiha, et.al. (2014) have concluded that five factors contribute general FL classroom: anxiety (Test anxiety and fear of failing the course), instructor, learner interaction, vocabulary, negative evaluation and self-confidence. Campos (2013) has tried to help EFL beginner students to communicate fluently by trying to find out the factors that influence EFL learners' oral communication. Campos has mentioned that: age or maturational constraints, aural medium, socio-cultural factors and affective factors may affect EFL learners' oral communication. Campos has concluded that learners should be encouraged to use the language and the teacher should use special activities that help learners to communicate successfully.

Mazouzi, (2013) has concluded that students face difficulties in using English in the classroom and that is due to psychological, linguistic and cognitive reasons. Mazouzi has recommended that there must be more attention to the learners' affective domains and particularly their selfesteem, motivation and anxiety to increase their academic level in oral performance positively.

Nazari \& Allahyar (2012) have discussed the instruction "Willingness to Communicate" (WTC) and how it contributes to the understanding of language learning.

$$
\text { مجلة كلية التربية- جامعة عين شمس } 24 \text { () العدد الأربعون (الجزء الرابع) } 2016
$$


Nazari \& Allahyar have found that learners' level of willingness to communicate (WTC) can vary based on the context. This shows that teachers need to adjust the teaching techniques they are using by considering all the dimensions of the classroom context. Riasati (2012) has investigated learners' perception of factors influencing willingness to speak English in language classrooms. The results of his study have revealed that a number of factors contribute to learners' willingness to speak such as: task type, topics of discussion, interlocutor, teacher, class atmosphere, personality and self-perceived speaking ability.

Gilakjani (2012) has found that all learners can do well in learning the pronunciation of a foreign language if the teacher and the learners participated together in the total learning process. Faliva (2012) has focused on the learner's role in oral communication in the EFL classroom. He has mentioned that the learner should participate with the teacher to achieve the goals of teaching. Altamiro (2006) has summed up his results that the teacher should be aware of the socio-cultural rules and factors to help him work towards pedagogical achievements, and the teacher should be able to improve classroom action so as to contribute for his students' development in language learning.

Savignoon \& Wang (2003) have discussed communicative language teaching in EFL context. The researchers have found out that adopting a communicationbased approach in many EFL context is very difficult. But, they have recommended that teaching for communicative competence appears to be the appropriate guiding principle of English pedagogy. Veronica de Andres (2002) has concluded that affective variables such as anxiety, motivation, self-esteem and inhibition can no longer be denied in the learning process. They affect the learning process negatively. Nishimura (2000) has tried to compare

$$
\text { مجلة كلية التربية- جامعة عين شمس } 25 \text { () العدد الواحد والأربعون (الجزء الاول) } 2017
$$


Factors Affecting Oral Communication In the EFL Classroom in Kuwait A Study

in the Higher Institute of Telecommunication and Navigation (HITN) in Kuwait

between different educational theories in order to find out the suitable theory to maximize learners' proficiency levels in communicative language reacting in Japan. He concluded that teachers are required to keep an appropriate balance between formal instruction to help learners acquire grammatical forms and communicative instruction that facilitate acquisition.

From all these studies, we can notice the importance of oral communication in learning a foreign language and how it leads to a successful learning. Moreover, the studies show that there are different factors that affect oral communication in EFL classroom. Some studies have focused on factors related to students such as: anxiety, low self-esteem, motivation, confidence, the feel of appreciation, the aural medium, age, task type, topics of discussion and class atmosphere. Other studies focused on the teacher and his role in enhancing oral communication in EFL classroom. Some studies recommended that the teacher should be a model for his students in his behavior and in encouraging oral communication in EFL classroom.

Some studies mentioned the role of the teaching methods in oral communication in the EFL classroom. Other studies mentioned that teaching methods in EFL classroom should balance between grammatical form and communicative instruction. Moreover, some studies focused on group-work strategies and their role in encouraging students to participate in oral communication in the class. Other studies suggested to employ more communicative strategies in the class. By going through all the previous results, the researcher of this study has decided to figure out factors that affect oral communication in EFL classroom in HITN in Kuwait since a lack of oral communication in EFL classroom has been noticed.

$$
\text { مجلة كلية التربية- جامعة عين شمس } 26 \text { () العدد الأربعون (الجزء الرابع) } 2016
$$




\section{Methodology}

\section{Participants}

The sample was randomly selected from The Higher Institution of Telecommunication and Navigation (HITN). A total of 100 students (50 males and 50 females) participated in responding to the questionnaire items. The age of students varied, $54.0 \%$ were $18-22$ years old, $38.0 \%$ were $23-27$ years old, $6.0 \%$ were $28-35$ years old, and only $2.0 \%$ were older than 35 years old. Year one students were $50 . \%$ as well as year four $50 \%$. According to students letter grade, A students were $32.0 \%$, B students were $32.0 \%$ as well, C students were $29,0 \%$, and D students were $7.0 \%$. Table (1) represents the demographic data of the participants.

Table (1) the Demographic Data of the Participants

\begin{tabular}{|c|c|c|c|c|}
\hline $\begin{array}{c}\text { Variable } \\
\text { Labels }\end{array}$ & $\begin{array}{l}\text { Value } \\
\text { Labels }\end{array}$ & Frequency & Valid \% & $\begin{array}{c}\text { Total } \\
\%\end{array}$ \\
\hline \multirow{2}{*}{ Gender } & Male & 50 & 50.0 & \multirow[t]{2}{*}{$100 \%$} \\
\hline & Female & 50 & 50.0 & \\
\hline \multirow{4}{*}{ Age } & $18-22$ & 54 & 54.0 & \multirow[t]{4}{*}{$100 \%$} \\
\hline & $23-27$ & 38 & 38.0 & \\
\hline & $28-35$ & 6 & 6.0 & \\
\hline & $\begin{array}{l}\text { Older than } \\
35\end{array}$ & 2 & 2.0 & \\
\hline \multirow{2}{*}{$\begin{array}{l}\text { Year of } \\
\text { Study }\end{array}$} & Year 1 & 50 & 50.0 & \multirow[t]{2}{*}{$100 \%$} \\
\hline & Year 4 & 50 & 50.0 & \\
\hline \multirow[t]{4}{*}{ Letter Grade } & $\mathrm{A}$ & 32 & 32.0 & \multirow[t]{4}{*}{$100 \%$} \\
\hline & B & 32 & 32.0 & \\
\hline & $\mathrm{C}$ & 29 & 29.0 & \\
\hline & D & 7 & 7.0 & \\
\hline
\end{tabular}

مجلة كلية التربية- جامعة عين ثمس 27 () العدد الواحد والأربعون (الجزء الاول) 2017 


\section{The Instrument}

A questionnaire was carefully developed to address the research questions. Some of the statements were adapted from previous literature and the rest were devised by the researcher. The questionnaire consisted of two parts. The first part sought the demographic data of the participants. The second part consisted of four domains covering a total of 43 items. Domain one (The role of the teacher in the communication process in the classroom) covered 11 items. Domain two (The role of the learner in the communication process in the classroom) consisted of 12 items. Domain three (The role of the syllabus in the communication process in the classroom) covered 9 items. Domain four (The role of the teaching methods in the communication process in the classroom) covered 11 items. In addition, findings according to the means of all items will be interpreted according to the following scale:

1) Less than 2.50 indicates low agreement.

2) Equal to 2.50 and less than 3.50 indicates moderate agreement.

3) More than 3.50 indicates high agreement.

\section{Instrument Reliability \& Validity}

\section{Reliability}

The reliability coefficient alpha of the questionnaire domains equals "0.776". This shows an acceptable consistency of reliability, which indicates that the questionnaire items were completely appropriate for research goals. Table (2) shows the reliability coefficients for the study instrument in its four domains.

$$
\text { مجلة كلية التربية- جامعة عين شمس } 28 \text { () العدد الأربعون (الجزء الرابع) } 2016
$$


(Jawaher Alrowayeh)

Table (2) the Reliability Coefficient for the Instrument

Domains

\begin{tabular}{|l|l|l|l|l|}
\hline $\begin{array}{l}\text { Variables } \\
\text { Labels }\end{array}$ & Means & $\begin{array}{l}\text { Std. } \\
\text { Deviation }\end{array}$ & $\begin{array}{l}\text { Cronbach's } \\
\text { Alpha }\end{array}$ & $\begin{array}{l}\text { No. of } \\
\text { Items }\end{array}$ \\
\hline Domain 1 & 2.371 & 0.356 & 0.797 & 11 \\
\hline Domain 2 & 2.957 & 0.367 & 0.789 & 12 \\
\hline Domain 3 & 2.330 & 0.542 & 0.768 & 9 \\
\hline Domain 4 & 2.465 & 0.539 & 0.725 & 11 \\
\hline Domain All & 2.554 & 0.319 & 0.776 & 43 \\
\hline
\end{tabular}

\section{Validity}

To examine the validity of the questionnaire items, the questionnaire was given to an expert in TEFL, and two teaching staff from the Department of Curriculum and Instruction from the College of Education in Kuwait University. Their comments were taken into consideration and they agreed that the items of the questionnaire are valid and reliable to conduct the research.

\section{Data Analysis}

The responses of the participants were manually coded. The Statistical Package for Social Sciences (SPSS) version 23 was used to enter the data. The descriptive statistics (i.e., the means, standard deviations and percentages) were calculated for the sake of the present study. In addition, t-test and One Way ANOVA were applied to answer the second research question.

\section{Findings and Discussion}

To answer the study questions, the researcher calculated percentages, means and standard deviations of the participants' responses. Results of the first through the fourth

$$
\text { مجلة كلية التربية- جامعة عين شمس } 29 \text { () العدد الواحد والأربعون (الجزء الاول) } 2017
$$



(HITN) in Kuwait

Question will be presented in forthcoming Tables 3, 4, 5 and 6 which show the participants' responses to the questionnaire items in its four domains.

First, data analysis and discussions of research question 1 "How does the teacher affect oral communication in EFL classroom"? Will be presented in Table (3).

Table (3)

Frequencies, Means and Standard Deviations' Distributions Regarding Teacher's Role

\begin{tabular}{|c|c|c|c|c|c|c|c|c|c|}
\hline $\begin{array}{l}\text { First Domain: } \\
\text { The role of the teacher in the oral } \\
\text { communication process in the } \\
\text { classroom }\end{array}$ & $\begin{array}{c}\text { Strongly } \\
\text { Agree } \\
\%\end{array}$ & $\begin{array}{l}\text { Agree } \\
\%\end{array}$ & $\begin{array}{c}\text { Not } \\
\text { Sure } \\
\%\end{array}$ & $\begin{array}{c}\text { Disagree } \\
\%\end{array}$ & $\begin{array}{c}\text { Strongly } \\
\text { Disagree } \\
\%\end{array}$ & Mean & St.D. & $\begin{array}{c}\text { Ranking of } \\
\text { Means }\end{array}$ & Scale \\
\hline 1) The teacher asks indirect questions & 5.0 & 19.0 & 26.0 & 37.0 & 13.0 & 3.34 & 1.085 & 3 & High \\
\hline 2) The teacher asks easy questions & 26.0 & 62.0 & 3.0 & 6.0 & 3.0 & 1.98 & 0.899 & 7 & Low \\
\hline $\begin{array}{l}\text { 3) The teacher encourages students to } \\
\text { communicate in the class }\end{array}$ & 56.0 & 39.0 & 3.0 & 2.0 & 0.0 & 1.51 & 0.659 & 11 & Low \\
\hline $\begin{array}{l}\text { 4) The teacher corrects students' errors } \\
\text { immediately }\end{array}$ & 55.0 & 39.0 & 2.0 & 2.0 & 2.0 & 1.57 & 0.807 & 10 & Low \\
\hline $\begin{array}{l}\text { 5) The teacher tries to set a } \\
\text { comfortable atmosphere in the } \\
\text { classroom }\end{array}$ & 5.0 & 3.0 & 9.0 & 40.0 & 43.0 & 4.13 & 1.041 & 1 & High \\
\hline
\end{tabular}

$$
\text { مجلة كلية التربية- جامعة عين شمس } 30 \text { () }
$$


(Jawaher Alrowayeh)

\begin{tabular}{|c|c|c|c|c|c|c|c|c|c|}
\hline $\begin{array}{l}\text { First Domain: } \\
\text { The role of the teacher in the oral } \\
\text { communication process in the } \\
\text { classroom }\end{array}$ & $\begin{array}{c}\text { Strongly } \\
\text { Agree } \\
\%\end{array}$ & $\begin{array}{c}\text { Agree } \\
\%\end{array}$ & $\begin{array}{c}\text { Not } \\
\text { Sure } \\
\%\end{array}$ & $\begin{array}{c}\text { Disagree } \\
\% \\
\%\end{array}$ & $\begin{array}{c}\text { Strongly } \\
\text { Disagree } \\
\%\end{array}$ & Mean & St.D. & $\begin{array}{c}\text { Ranking of } \\
\text { Means }\end{array}$ & Scale \\
\hline $\begin{array}{l}\text { 6) The teacher does not accept } \\
\text { students' errors }\end{array}$ & 50.0 & 42.0 & 3.0 & 4.0 & 1.0 & 1.64 & 0.811 & 9 & Low \\
\hline $\begin{array}{l}\text { 7) The teacher encourages students to } \\
\text { talk freely }\end{array}$ & 34.0 & 36.0 & 8.0 & 20.0 & 2.0 & 2.20 & 1.172 & 4 & Low \\
\hline $\begin{array}{l}\text { 8) The teacher explains difficult points } \\
\text { of the lesson in Arabic }\end{array}$ & 36.0 & 48.0 & 7.0 & 5.0 & 4.0 & 1.93 & 0.998 & 8 & Low \\
\hline $\begin{array}{l}\text { 9) The teacher uses English most of } \\
\text { the time in the classroom }\end{array}$ & 33.0 & 42.0 & 15.0 & 8.0 & 2.0 & 2.05 & 0.994 & 5 & Low \\
\hline $\begin{array}{l}\text { 10) The teacher praises students when } \\
\text { they answer correctly }\end{array}$ & 33.0 & 38.0 & 23.0 & 4.0 & 2.0 & 2.04 & 0.953 & 6 & Low \\
\hline $\begin{array}{l}\text { 11) The teacher uses difficult terms } \\
\text { when explaining new lesson }\end{array}$ & 5.0 & 9.0 & 15.0 & 53.0 & 18.0 & 3.70 & 1.030 & 2 & High \\
\hline
\end{tabular}

Based on Table (3), it shows that the degree of students' agreement with the domain items was low according to the means presented earlier, as the mean was (2.371) and the standard deviation was $(0.356)$. 
Factors Affecting Oral Communication In the EFL Classroom in Kuwait A Study

in the Higher Institute of Telecommunication and Navigation (HITN) in Kuwait

Among the eleven items presented in this domain, the highest means are found in items 5, 11, and1. These first three high means of the domain items will be interpreted in a descending order. First, item 5 (The teacher tries to set a comfortable atmosphere in the classroom) is found to be a main factor that discourages students from being communicatively active in the language classroom as the mean was (4.13) and the standard deviation was (1.041). Second comes item 11 (The teacher uses difficult terms when explaining new lesson) with a mean of (3.70) and a standard deviation of (1. 030). Third comes item 1 (The teacher asks indirect questions) with a mean of (3.34) and a standard deviation of (1.085).

The lowest means are found in items 3, 4, and 6 as follows. In item 3 (The teacher encourages students to communicate in the class), with a mean of (1.51) and a standard deviation of (.659). Then comes item 4 (The teacher corrects students' errors immediately) as the mean was (1.57) and the standard deviation was (0.807). Finally comes item 6 (The teacher does not accept students' errors) as the mean was (1.64) and the standard deviation was (.811). The means of these three items were low.

The findings of this domain reveal that the majority of the participants agree that teachers encourage them to communicate in the class. This result contradicts what Mazouzi (2013) has found in her study that around 64\% of the participants in her study do not feel that they are motivated to speak in English. This factor of students' motivation was emphasized by Campos, (2013) as a factor that plays a great role in helping students to communicate fluently in EFL classroom. Also, the role of the teacher in encouraging and supporting students in EFL classroom was discussed by Rodriguez \& Barrera, (2015).

$$
\text { مجلة كلية التربية- جامعة عين شمس } 32 \text { () العدد الأربعون (الجزء الرابع) } 2016
$$


(Jawaher Alrowayeh)

Although the results show that more than $90 \%$ of the participants agree that teachers correct students' errors immediately, more than $90 \%$ of them think that teachers do not accept students' errors. These findings are consistent with the results found by Kuutila, (2014). Around $80 \%$ of the participants feel that teachers do not set a comfortable atmosphere in the classroom while in Mazouzi (2013) study, the results revealed that more than half of the participants feel comfortable in oral participation in the class. Around $80 \%$ of the participants agree that teachers explain difficult points of the lesson in Arabic. $70 \%$ of the respondents think that teachers do not use difficult terms when explaining a new lesson and that teachers use English most of the time in the classroom. These results were discussed by Kuutila, (2014) as factors that affect learners' willingness to communicate.

The analysis of the results revealed that around $88 \%$ of the participants think that teachers ask easy questions and $70 \%$ of them agree that teachers encourage students to talk freely in the classroom. This result contradicts what Mazouzi (2013) has found that only $12.5 \%$ of the teachers in her study use discussion in the class of English. Also, $70 \%$ of the respondents agree that teachers praise students when they answer correctly. Similar results were found by Nazari \& Allahyar, (2012).

Second, data analysis and discussions of research question 2 "How does the student affect oral communication in EFL classroom"? Will be presented in Table (4).

العدد الواحد والأربعون (الجزء الاول) 2017

مجلة كلية التربية- جامعة عين شمس 33 () 

(Jawaher Alrowayeh)

Table (4)

Frequencies, Means and Standard Deviations' Distributions Regarding Learners' Role

\begin{tabular}{|c|c|c|c|c|c|c|c|c|c|}
\hline $\begin{array}{l}\text { Second Domain: } \\
\text { The role of the learner in the oral } \\
\text { communication process in the } \\
\text { classroom }\end{array}$ & $\begin{array}{c}\text { Strongly } \\
\text { Agree } \\
\%\end{array}$ & $\begin{array}{c}\text { Agree } \\
\%\end{array}$ & $\begin{array}{c}\text { Not } \\
\text { Sure } \\
\%\end{array}$ & $\begin{array}{c}\text { Disagree } \\
\%\end{array}$ & $\begin{array}{c}\text { Strongly } \\
\text { Disagree } \\
\%\end{array}$ & Mean & St.D. & $\begin{array}{c}\text { Ranking } \\
\text { of } \\
\text { Means }\end{array}$ & Scale \\
\hline $\begin{array}{l}\text { 1) I usually communicate in the class } \\
\text { of English }\end{array}$ & 17.0 & 53.0 & 18.0 & 11.0 & 1.0 & 2.262 & 0.906 & 11 & Low \\
\hline $\begin{array}{l}\text { 2) I use the English language when I } \\
\text { communicate in the class }\end{array}$ & 13.0 & 47.0 & 17.0 & 22.0 & 1.0 & 2.51 & 1.010 & 10 & Moderate \\
\hline 3) I feel anxious in the class of English & 13.0 & 22.0 & 7.0 & 32.0 & 26.0 & 3.36 & 1.411 & 3 & Moderate \\
\hline $\begin{array}{l}\text { 4) I feel embarrassed when I make } \\
\text { mistakes in English }\end{array}$ & 8.0 & 28.0 & 10.0 & 39.0 & 15.0 & 3.25 & 1.242 & 6 & Moderate \\
\hline $\begin{array}{l}\text { 5) The students laugh at any student } \\
\text { when he makes a mistake in English }\end{array}$ & 7.0 & 10.0 & 16.0 & 34.0 & 33.0 & 3.76 & 1.215 & 1 & High \\
\hline $\begin{array}{l}\text { 6) I can ask my teacher using the } \\
\text { English language easily }\end{array}$ & 9.0 & 56.0 & 15.0 & 12.0 & 8.0 & 2.54 & 1.077 & 9 & Moderate \\
\hline
\end{tabular}

مجلة كلية التربية- جامعة عين شمس 2017 () العدد الواحد والأربعون (الجزء الاول) 
Factors Affecting Oral Communication In the EFL Classroom in Kuwait A Study in the Higher Institute of Telecommunication and Navigation (HITN) in Kuwait

\begin{tabular}{|c|c|c|c|c|c|c|c|c|c|}
\hline $\begin{array}{l}\text { Second Domain: } \\
\text { The role of the learner in the oral } \\
\text { communication process in the } \\
\text { classroom }\end{array}$ & $\begin{array}{c}\text { Strongly } \\
\text { Agree } \\
\%\end{array}$ & $\begin{array}{c}\text { Agree } \\
\%\end{array}$ & $\begin{array}{c}\text { Not } \\
\text { Sure } \\
\%\end{array}$ & $\begin{array}{c}\text { Disagree } \\
\%\end{array}$ & $\begin{array}{c}\text { Strongly } \\
\text { Disagree } \\
\%\end{array}$ & Mean & St.D. & $\begin{array}{c}\text { Ranking } \\
\text { of } \\
\text { Means }\end{array}$ & Scale \\
\hline $\begin{array}{l}\text { 7) I appreciate the importance of the } \\
\text { English language in our lives }\end{array}$ & 50.0 & 36.0 & 8.0 & 2.0 & 4.0 & 1.74 & 0.981 & 12 & Low \\
\hline $\begin{array}{l}\text { 8) I communicate with my peers in the } \\
\text { class in English }\end{array}$ & 6.0 & 30.0 & 9.0 & 40.0 & 15.0 & 3.28 & 1.215 & 4 & Moderate \\
\hline $\begin{array}{l}\text { 9) I use the English language } \\
\text { confidently }\end{array}$ & 5.0 & 37.0 & 24.0 & 22.0 & 12.0 & 2.99 & 1.133 & 7 & Moderate \\
\hline $\begin{array}{l}\text { 10) I communicate in English outside } \\
\text { the classroom }\end{array}$ & 7.0 & 25.0 & 18.0 & 34.0 & 16.0 & 3.27 & 1.205 & 5 & Moderate \\
\hline $\begin{array}{l}\text { 11) I face some difficulties in speaking } \\
\text { English }\end{array}$ & 8.0 & 38.0 & 17.0 & 27.0 & 10.0 & 2.93 & 1.174 & 8 & Moderate \\
\hline
\end{tabular}

$$
\text { مجلة كلية التربية- جامعة عين شنم } 34 \text { () العدد الأربعون (الجزء الرابع) } 2016
$$


(Jawaher Alrowayeh)

\begin{tabular}{|c|c|c|c|c|c|c|c|c|c|}
\hline $\begin{array}{l}\text { Second Domain: } \\
\text { The role of the learner in the oral } \\
\text { communication process in the } \\
\text { classroom }\end{array}$ & $\begin{array}{c}\text { Strongly } \\
\text { Agree } \\
\%\end{array}$ & $\begin{array}{c}\text { Agree } \\
\%\end{array}$ & $\begin{array}{c}\text { Not } \\
\text { Sure } \\
\%\end{array}$ & $\begin{array}{c}\text { Disagree } \\
\%\end{array}$ & $\begin{array}{c}\text { Strongly } \\
\text { Disagree } \\
\%\end{array}$ & Mean & St.D. & $\begin{array}{c}\text { Ranking } \\
\text { of } \\
\text { Means }\end{array}$ & Scale \\
\hline $\begin{array}{l}\text { 12) I don't understand what the } \\
\text { teacher is saying in English }\end{array}$ & 3.0 & 20.0 & 14.0 & 41.0 & 22.0 & 3.59 & 1.129 & 2 & High \\
\hline
\end{tabular}

Table (4), shows that the degree of students' agreement with the domain items was moderate according to the means' scale presented earlier, as the mean was (2.957) and the standard deviation was (0.367). Among the twelve items presented in this domain, the highest three means are found in items 5, 12, 
Factors Affecting Oral Communication In the EFL Classroom in Kuwait A Study

in the Higher Institute of Telecommunication and Navigation (HITN) in Kuwait

and 3. These first three high means of the domain items will be interpreted in a descending order. First, item 5 (The students laugh at any student when he makes a mistake in English) is found to be a major factor that discourages students from classroom communication in the language classroom as the mean was (3.76) and the standard deviation was (1.215). Second comes item 12 (I don't understand what the teacher is saying in English) with a mean of (3.59) and a standard deviation of (1.129). Third comes item 3 (I feel anxious in the class of English) with a mean of (3.36) and a standard deviation of (1.411). The mean of this item although scored the third position among the items, its mean is moderate according to the scale.

The lowest means are found in items 7, 1, and 2 as follows. In item 7 (I appreciate the importance of the English language in our lives), with a mean of (1.74) and a standard deviation of (.981). Then comes item 1 (I usually communicate in the class of English) as the mean was (2.26) and the standard deviation was (0.807). Finally comes item 2 (I use the English language when I communicate in the class) as the mean was (2.51) and the standard deviation was (1.010). The means of these three items were low.

The findings of this domain indicate that around $70 \%$ of the respondents communicate in English in the classroom. This result contradicts what Abebe, et.al. (2014) have found that $70 \%$ of their participants are reluctant to participate in the class because they are not interested in English. This result has a great impact on learning English as EFL as was discussed by Mazouzi, (2013). Around 35\% of the participants feel anxious in the class of English and feel embarrassed when making mistakes although, $60 \%$ of the respondents reveal that students do not laugh at any student when making a mistake. While in the study of Abebe, et.al.

$$
\text { مجلة كلية التربية- جامعة عين شمس } 36 \text { () العدد الأربعون (الجزء الرابع) } 2016
$$


(2014) we can find that the fear of making mistakes and being laughed at are one of the main causes of perceived reticence. The feeling of anxiety and inhibition was discussed by Veronica de Andres, (2002) and Batiha, et.al. (2014) as a negative factor that influence EFL learning.

The majority of the respondents appreciate the importance of the English language in our lives but around $50 \%$ of them do not communicate in English with their peers in the classroom or outside the classroom. The factor of communicating in the EFL classroom was emphasized by Faliva, (2012). He has found that the student's role is to get involved and to participate with the teacher to achieve the goals of teaching. Also, this factor was discussed by Mazouzi, (2013) as an important factor for communicating in EFL classroom. The results also revealed that around $40 \%$ of the participants can use the English language confidently however, around $35 \%$ of them show their disability to use the language confidently. Around $40 \%$ of the respondents express that they face difficulties in speaking English. The same findings were proved by (Abebe, at.al. 2014) in their study.

Third, data analysis and discussions of research question 3 "How does the syllabus affect oral communication in EFL classroom?" will be presented in Table (5). 
Factors Affecting Oral Communication In the EFL Classroom in Kuwait A Study in the Higher Institute of Telecommunication and Navigation (HITN) in Kuwait

\section{Table (5)}

Frequencies, Means and Standard Deviations' Distributions Regarding the Syllabus

\begin{tabular}{|c|c|c|c|c|c|c|c|c|c|}
\hline $\begin{array}{l}\text { Third Domain: } \\
\text { The role of syllabus in the communication } \\
\text { process in the classroom }\end{array}$ & $\begin{array}{c}\text { Strongly } \\
\text { Agree } \\
\%\end{array}$ & $\begin{array}{c}\text { Agree } \\
\%\end{array}$ & $\begin{array}{c}\text { Not } \\
\text { Sure } \\
\%\end{array}$ & $\begin{array}{c}\text { Disagree } \\
\%\end{array}$ & $\begin{array}{c}\text { Strongly } \\
\text { Disagree } \\
\%\end{array}$ & Mean & St.D. & $\begin{array}{c}\text { Ranking } \\
\text { of } \\
\text { Means }\end{array}$ & Scale \\
\hline $\begin{array}{l}\text { 1) The syllabus includes some questions for } \\
\text { oral communication }\end{array}$ & 18.0 & 61.0 & 18.0 & 2.0 & 1.0 & 2.07 & 0.728 & 8 & Low \\
\hline $\begin{array}{l}\text { 2) The syllabus concentrates on different } \\
\text { skills of the language: reading, writing, } \\
\text { listening and speaking }\end{array}$ & 29.0 & 51.0 & 11.0 & 8.0 & 1.0 & 2.01 & 0.904 & 9 & Low \\
\hline $\begin{array}{l}\text { 3) There are several tasks for listening in the } \\
\text { syllabus }\end{array}$ & 15.0 & 58.0 & 16.0 & 10.0 & 1.0 & 2.24 & 0.866 & 4 & Low \\
\hline $\begin{array}{l}\text { 4) There are several tasks for speaking in the } \\
\text { syllabus }\end{array}$ & 19.0 & 56.0 & 12.0 & 12.0 & 1.0 & 2.20 & 0.921 & 5 & Low \\
\hline 5) We have oral speaking tests & 7.0 & 29.0 & 37.0 & 21.0 & 6.0 & 2.90 & 1.010 & 2 & Moderate \\
\hline
\end{tabular}

$$
\text { مجلة كلية التربية- جامعة عين شنس } 38 \text { () العدد الأربعون (الجزء الرابع) }
$$


(Jawaher Alrowayeh)

\begin{tabular}{|c|c|c|c|c|c|c|c|c|c|}
\hline $\begin{array}{l}\text { Third Domain: } \\
\text { The role of syllabus in the communication } \\
\text { process in the classroom }\end{array}$ & $\begin{array}{c}\text { Strongly } \\
\text { Agree } \\
\%\end{array}$ & $\begin{array}{c}\text { Agree } \\
\%\end{array}$ & $\begin{array}{c}\text { Not } \\
\text { Sure } \\
\%\end{array}$ & $\begin{array}{c}\text { Disagree } \\
\%\end{array}$ & $\begin{array}{c}\text { Strongly } \\
\text { Disagree } \\
\%\end{array}$ & Mean & St.D. & $\begin{array}{c}\text { Ranking } \\
\text { of } \\
\text { Means }\end{array}$ & Scale \\
\hline 6) There are specific marks for presentation & 7.0 & 23.0 & 45.0 & 19.0 & 6.0 & 2.94 & 0.973 & 1 & Moderate \\
\hline 7) We do some exercises in groups & 15.0 & 53.0 & 15.0 & 15.0 & 2.0 & 2.50 & 0.980 & 3 & Moderate \\
\hline $\begin{array}{l}\text { 8) Group work encourages students to use } \\
\text { English }\end{array}$ & 26.0 & 48.0 & 17.0 & 8.0 & 1.0 & 2.10 & 0.916 & 7 & Low \\
\hline $\begin{array}{l}\text { 9) The syllabus concentrates on using } \\
\text { grammar }\end{array}$ & 22.0 & 52.0 & 17.0 & 7.0 & 2.0 & 2.15 & 0.914 & 6 & Low \\
\hline
\end{tabular}


Factors Affecting Oral Communication In the EFL Classroom in Kuwait A Study

in the Higher Institute of Telecommunication and Navigation (HITN) in Kuwait

Based on Table (5), data show that the degree of students' agreement with the domain items was low according to the means' scale presented earlier, as the mean was (2.330) and the standard deviation was (0.542). Among the nine items presented in this domain, the highest three means are found in items 6,5 , and 7 which represent a moderate scale of agreement. These first three high means of the domain items will be interpreted in a descending order. First, item 6 (There are specific marks for presentation) is found to be an important factor that discourages students from classroom communication in the language classroom as the mean was (2.94) and the standard deviation was (.973). Second comes item 5 (We have oral speaking tests) with a mean of (2.90) and a standard deviation of (1.010). Third comes item 7 (We do some exercises in groups) with a mean of (2.50) and a standard deviation of (.980). The mean of this item although scored the third position among the items, its mean is moderate according to the scale.

The lowest means are found in items 8, 1, and 2 as follows. In item 8 (Group work encourages students to use English), with a mean of (2.10) and a standard deviation of (.916). Then comes item 1 (The syllabus includes some questions for oral communication) as the mean was (2.07) and the standard deviation was (.728). Finally comes item 2 (The syllabus concentrates on different skills of the language: reading, writing, listening and speaking) as the mean was (2.01) and the standard deviation was (.904). The means of these three items were low.

The findings of this domain point out that around $80 \%$ of the participants think that the syllabus includes some questions for oral communication and that the syllabus concentrates on different skills of the language. Moreover, more than half of the participants reveal that the syllabus

$$
\text { مجلة كلية التربية- جامعة عين شمس } 40 \text { () العدد الأربعون (الجزء الرابع) } 2016
$$


(Jawaher Alrowayeh)

includes several tasks for listening and for speaking. Gilakjani, (2012) discussed the importance of the integrated content of the syllabus as a great factor on EFL learners. The factor of task type was discussed by Abebe, et.al.(2014) as a factor that influences students' participation in the EFL classroom.

Regarding the items that ask about oral speaking tests and presentation, most of the students were not sure about those activities. While in the study of (Abebe, at.al. 2014), the results have shown that presentations in the class have been reported to be highly anxiety inducing. More than half of the participants agree that group work encourages students to use English and that they do some exercises in groups. While in Kuutila (2014) study, the results have shown that $64 \%$ of the respondents mentioned some of group-related issues that may influence oral communication such as the atmosphere in the class, group pressure into using English and how well the students know each other. The importance of group work as a class activity that affect communication in EFL classroom was recommended by many researchers such as Nishimura, (2000), Riasati, (2012), Kuutila, (2014), Rodriguez \& Barrera, (2015). Also, around $70 \%$ of the participants agree that the syllabus concentrates on using grammar. This factor was discussed by Savignoon \& Wang, (2003) as a factor that affect communication in EFL classroom negatively.

Fourth, data analysis and discussions of research question "4" How do methods of teaching affect oral communication in EFL classroom?" will be presented in Table (6).

العدد الواحد والأربعون (الجزء الاول) 2017 مجلة كلية التربية- جامعة عين شمس 
Factors Affecting Oral Communication In the EFL Classroom in Kuwait A Study in the Higher Institute of Telecommunication and Navigation (HITN) in Kuwait

\section{Table (6)}

Frequencies, Means and Standard Deviations' Distributions Regarding the Teaching Methods

\begin{tabular}{|c|c|c|c|c|c|c|c|c|c|}
\hline $\begin{array}{l}\text { Fourth Domain: } \\
\text { The role of teaching methods in the } \\
\text { communicate process in the classroom }\end{array}$ & $\begin{array}{c}\text { Strongly } \\
\text { Agree } \\
\%\end{array}$ & $\begin{array}{c}\text { Agree } \\
\%\end{array}$ & $\begin{array}{c}\text { Not } \\
\text { Sure } \\
\%\end{array}$ & $\begin{array}{c}\text { Disagree } \\
\%\end{array}$ & $\begin{array}{c}\text { Strongly } \\
\text { Disagree } \\
\%\end{array}$ & Mean & St.D. & $\begin{array}{c}\text { Ranking } \\
\text { of } \\
\text { Means }\end{array}$ & Scale \\
\hline $\begin{array}{l}\text { 1) The communicative activities help learners to } \\
\text { interact in English }\end{array}$ & 26.0 & 52.0 & 12.0 & 10.0 & 0.0 & 2.06 & 0.888 & 9 & Low \\
\hline $\begin{array}{l}\text { 2) The teacher uses a variety of teaching methods } \\
\text { in the class }\end{array}$ & 27.0 & 51.0 & 8.0 & 13.0 & 1.0 & 2.10 & 0.980 & 8 & Low \\
\hline $\begin{array}{l}\text { 3) The teacher concentrates on group work method } \\
\text { in the class }\end{array}$ & 17.0 & 42.0 & 24.0 & 13.0 & 4.0 & 2.45 & 1.048 & 5 & Low \\
\hline $\begin{array}{l}\text { 4) The teacher uses recordings for listening } \\
\text { exercises }\end{array}$ & 7.0 & 18.0 & 28.0 & 32.0 & 15.0 & 3.30 & 1.142 & 1 & Moderate \\
\hline $\begin{array}{l}\text { 5) The teacher uses the discussion method in the } \\
\text { class }\end{array}$ & 31.0 & 51.0 & 12.0 & 5.0 & 1.0 & 1.94 & 0.851 & 11 & Low \\
\hline $\begin{array}{l}\text { 6) The teacher asks students to write a dialogue and } \\
\text { then perform it }\end{array}$ & 12.0 & 20.0 & 27.0 & 26.0 & 15.0 & 3.12 & 1.241 & 2 & Moderate \\
\hline
\end{tabular}

$$
\text { بجلة كلية التربية- جامعة عين شمس } 42016 \text { () العدد الأربعون (الجزء الرابع) }
$$


(Jawaher Alrowayeh)

\begin{tabular}{|c|c|c|c|c|c|c|c|c|c|}
\hline $\begin{array}{c}\text { Fourth Domain: } \\
\text { The role of teaching methods in the } \\
\text { communicate process in the classroom }\end{array}$ & $\begin{array}{c}\text { Strongly } \\
\text { Agree } \\
\%\end{array}$ & $\begin{array}{c}\text { Agree } \\
\%\end{array}$ & $\begin{array}{c}\text { Not } \\
\text { Sure } \\
\%\end{array}$ & $\begin{array}{c}\text { Disagree } \\
\%\end{array}$ & $\begin{array}{c}\text { Strongly } \\
\text { Disagree } \\
\%\end{array}$ & Mean & St.D. & $\begin{array}{c}\text { Ranking } \\
\text { of } \\
\text { Means }\end{array}$ & Scale \\
\hline $\begin{array}{l}\text { 7) The method of role playing encourages students } \\
\text { to communicate in English }\end{array}$ & 17.0 & 38.0 & 20.0 & 20.0 & 5.0 & 2.58 & 1.139 & 4 & Moderate \\
\hline $\begin{array}{l}\text { 8) The skill of oral communication is used a lot in } \\
\text { the class }\end{array}$ & 20.0 & 46.0 & 23.0 & 9.0 & 2.0 & 2.27 & 0.952 & 7 & Low \\
\hline $\begin{array}{l}\text { 9) There is a great concentration on grammar in the } \\
\text { class }\end{array}$ & 25 & 52 & 17 & 6 & 0.0 & 2.04 & 0.816 & 10 & Low \\
\hline $\begin{array}{l}\text { 10) The teacher often prepares activities for } \\
\text { interacting with peers in the class }\end{array}$ & 18.0 & 43.0 & 22.0 & 11.0 & 6.0 & 2.44 & 1.095 & 6 & Low \\
\hline 11) There should be an oral speaking test & 13.0 & 34.0 & 24.0 & 16.0 & 13.0 & 2.82 & 1.234 & 3 & Moderate \\
\hline
\end{tabular}

ججلة كلية التربية- جامعة عين شمس 43 () العدد الواحد والأربعون (الجزء الاول) 2017 
Factors Affecting Oral Communication In the EFL Classroom in Kuwait A Study

in the Higher Institute of Telecommunication and Navigation (HITN) in Kuwait

Table (6), above indicates that the degree of students' agreement with the domain items was low according to the means' scale presented earlier, as the mean was (2.465) and the standard deviation was (0.539). Among the nine items presented in this domain, the highest three means are found in items 4, 6, and 11 which represent a moderate scale of agreement. These first three high means of the domain items will be interpreted in a descending order. First, item 4 (The teacher uses recordings for listening exercises) is found to be an important factor that discourages students from classroom communication in the language classroom as the mean was (3.30) and the standard deviation was (1.142). Second comes item 6 (The teacher asks students to write a dialogue and then perform) with a mean of (3.12) and a standard deviation of (1.241). Third comes item 11 (There should be an oral speaking test) with a mean of (2.82) and a standard deviation of (1.234). The mean of this item although scored the third position among the items, its mean is moderate according to the scale.

The lowest means are found in items 1, 9, and 5 as follows. In item 1 (The communicative activities help learners to interact in English), with a mean of (2.06) and a standard deviation of (.886). Then comes item9 (There is a great concentration on grammar in the class) as the mean was (2.04) and the standard deviation was (.816) . Finally comes item 5 (The teacher uses the discussion method in the class) as the mean was (1.94) and the standard deviation was (.851). The means of these three items were low.

The findings of this domain reveal that more than half of the participants think that teachers use a variety of teaching methods in the class and that the communicative activities help learners to interact in English. This result goes along with other studies like Savignoon \& Wang, (2003) and

$$
\text { مجلة كلية التربية- جامعة عين شمس } 44 \text { () العدد الأربعون (الجزء الرابع) } 2016
$$


Campos, (2013). Moreover, the results reveal that more than $80 \%$ of the participants agree that teachers use the discussion method in the class. Also, the results show that more than half of the participants think that the skill of oral communication is used a lot and at the same time, that there is a great concentration on grammar in the class. Nishimura, (2000), has recommended that teachers are required to keep an appropriate balance between formal instruction that helps learners acquire grammatical forms and communicative instruction that helps facilitate acquisition.

Around $60 \%$ of the participants agree that teachers often prepare activities for interacting with peers in the classroom. Nazari \& Allahyar, (2012) have concluded that choosing the suitable teaching strategies will encourage students to communicate. Around $70 \%$ of the participants disagree that teachers use recordings for listening exercises whereas around $25 \%$ of them agree on that item. Around $41 \%$ of the participants show disagreement on the item that teachers ask students to write a dialogue and then perform it whereas $32 \%$ of them agree on that item. $55 \%$ of the participants agree that the methods of role playing encourage students to communicate in English whereas 24\% of them do not agree. $47 \%$ of the participants think that there should be an oral speaking test whereas $30 \%$ of the participants disagree.

\section{Results Related to the Fifth Question}

The fifth question intends to test the existence of significant effects of gender, year of study, age of students and students' letter grade according to the factors which discourages their classroom communication. Tables 6, 7, 8, 9 and 10 show the means and standard deviations of the students' responses as t-test and One Way ANOVA were applied.

$$
\text { مجلة كلية التربية- جامعة عين شمس } 45 \text { () العدد الواحد والأربعون (الجزء الاول) } 2017
$$


Factors Affecting Oral Communication In the EFL Classroom in Kuwait A Study in the Higher Institute of Telecommunication and Navigation (HITN) in Kuwait

\begin{tabular}{|c|c|c|c|c|c|c|c|c|c|}
\hline \multicolumn{10}{|c|}{$\begin{array}{c}\text { Table (7) T-test Differences between Total of Answers According to the } \\
\text { Demographic Variable of Gender. }\end{array}$} \\
\hline \multirow{2}{*}{$\begin{array}{l}\text { Variable } \\
\text { Names }\end{array}$} & \multicolumn{3}{|c|}{ Male } & \multicolumn{3}{|c|}{ Female } & \multirow{2}{*}{$\mathbf{T}$} & \multirow{2}{*}{ Df } & \multirow{2}{*}{$\begin{array}{c}\text { Sig. } \\
(2- \\
\text { tailed })\end{array}$} \\
\hline & $\mathbf{N}$ & Mean & $\begin{array}{c}\text { Std. } \\
\text { Deviation }\end{array}$ & $\mathbf{N}$ & Mean & $\begin{array}{c}\text { Std. } \\
\text { Deviation }\end{array}$ & & & \\
\hline Domain 1 & 50 & 2.340 & .3164 & 50 & 2.402 & .3733 & -.893 & 98 & .374 \\
\hline Domain 2 & 50 & 2.963 & .3504 & 50 & 2.950 & .3854 & .181 & 98 & .857 \\
\hline Domain 3 & 50 & 2.256 & .5786 & 50 & 2.404 & .4978 & -1.379 & 98 & .171 \\
\hline Domain 4 & 50 & 2.371 & .5595 & 50 & 2.560 & .5061 & -1.772 & 98 & .079 \\
\hline
\end{tabular}

Table ( 7 ) shows that there were no significant differences between the total of answers according to 'Gender' with reference to the study domains as the level of significance is $p \geq 0.05$.

$$
\text { مجلة كلية التربية- جامعة عين شمس } 46 \text { () العدد الأربعون (الجزء الرابع) }
$$


(Jawaher Alrowayeh)

Table (8) T-test Differences between Total of Answers According to the Demographic Variable of Year of Study.

\begin{tabular}{|c|c|c|c|c|c|c|c|c|c|}
\hline \multirow{2}{*}{$\begin{array}{c}\text { Variable } \\
\text { Names }\end{array}$} & \multicolumn{3}{|c|}{ Female } & \multicolumn{3}{|c|}{ Male } & \multirow{2}{*}{$\mathbf{T}$} & \multirow{2}{*}{ Df } & \multirow{2}{*}{$\begin{array}{c}\text { Sig. } \\
(2- \\
\text { tailed })\end{array}$} \\
\hline & $\mathbf{N}$ & Mean & $\begin{array}{c}\text { Std. } \\
\text { Deviation }\end{array}$ & $\mathbf{N}$ & Mean & $\begin{array}{c}\text { Std. } \\
\text { Deviation }\end{array}$ & & & \\
\hline Domain 1 & 50 & 2.352 & 0.315 & 50 & 2.453 & 0.387 & -.877 & 98 & 0.366 \\
\hline Domain 2 & 50 & 2.854 & 0.3512 & 50 & 2.873 & 0.356 & 0.192 & 98 & 0.768 \\
\hline Domain 3 & 50 & 2.624 & 0.579 & 50 & 2.425 & 0.489 & -1.368 & 98 & 0.192 \\
\hline Domain 4 & 50 & 2.291 & 0.564 & 50 & 2.642 & 0.574 & -1.793 & 98 & 0.096 \\
\hline
\end{tabular}

Table ( 8 ) shows that there were no significant differences between the total of answers according to 'Year of Study' with reference to the study domains as the level of significance is $p \geq 0.05$. 
Factors Affecting Oral Communication In the EFL Classroom in Kuwait A Study in the Higher Institute of Telecommunication and Navigation (HITN) in Kuwait

\section{Table (9) F-Test (ANOVA) by Age of Students}

\begin{tabular}{|l|c|l|l|c|c|c|}
\hline $\begin{array}{l}\text { Variable } \\
\text { Labels }\end{array}$ & Source & D.F & \multicolumn{1}{l}{$\begin{array}{l}\text { Sum } \\
\text { Squares }\end{array}$} & Mean Square & $\begin{array}{l}\text { F- } \\
\text { Ratio }\end{array}$ & Sig. \\
\hline Domain 1 & Between Groups & 3 & .559 & .186 & 1.587 & .198 \\
\cline { 2 - 6 } & Within Groups & 96 & 11.270 & .117 & & \\
\hline Domain 2 & Between Groups & 3 & .378 & .126 & .935 & .427 \\
\cline { 2 - 6 } & Within Groups & 96 & 12.921 & .135 & & \\
\hline Domain 3 & Between Groups & 3 & .695 & .232 & .784 & .506 \\
\cline { 2 - 6 } & Within Groups & 96 & 28.402 & .296 & & \\
\hline Domain 4 & Between Groups & 3 & .917 & .306 & 1.054 & .511 \\
\cline { 2 - 6 } & Within Groups & 96 & 27.864 & .290 & & \\
\hline
\end{tabular}

Table ( 9 ) shows that there were no significant differences between the total of answers according to 'Age of Students' with reference to the study domains as the level of significance is $\mathrm{p} \geq 0.05$.

$$
\text { مجلة كلية التربية- جامعة عين شمس } 48016 \text { () العدد الأربعون (الجزء الرابع) }
$$


(Jawaher Alrowayeh)

\begin{tabular}{|c|c|c|c|c|c|c|}
\hline \multicolumn{7}{|c|}{ Table ( 10 ) F-Test (ANOVA) by Students Letter Grade } \\
\hline $\begin{array}{l}\text { Variable } \\
\text { Labels }\end{array}$ & Source & D.F & $\begin{array}{l}\text { Sum of } \\
\text { Squares }\end{array}$ & Mean Square & $\begin{array}{l}\text { F- } \\
\text { Ratio }\end{array}$ & Sig. \\
\hline \multirow[t]{2}{*}{ Domain 1} & Between Groups & 3 & .584 & .195 & \multirow[t]{2}{*}{1.662} & \multirow[t]{2}{*}{.180} \\
\hline & Within Groups & 96 & 11.245 & .117 & & \\
\hline \multirow[t]{2}{*}{ Domain 2} & Between Groups & 3 & .248 & .083 & \multirow[t]{2}{*}{.608} & \multirow[t]{2}{*}{.612} \\
\hline & Within Groups & 96 & 13.051 & .136 & & \\
\hline \multirow[t]{2}{*}{ Domain 3} & Between Groups & 3 & 1.953 & .651 & \multirow[t]{2}{*}{2.302} & \multirow[t]{2}{*}{.082} \\
\hline & Within Groups & 96 & 27.145 & .283 & & \\
\hline \multirow[t]{2}{*}{ Domain4 } & Between Groups & 3 & .561 & .187 & \multirow[t]{2}{*}{.636} & \multirow[t]{2}{*}{.594} \\
\hline & Within Groups & 96 & 28.221 & .294 & & \\
\hline
\end{tabular}

Table ( 10 ) shows that there were no significant differences between the total of answers according to 'Students Letter Grade' with reference to the study domains as the level of significance is $\mathrm{p} \geq 0.05$. Discussion of Results 
Based on the results of the previous domains, most of the participants have revealed that teachers do not set a comfortable atmosphere in the EFL classroom. Also, the results have shown that teachers do not accept student's errors and they tend to correct students' errors immediately. From those results we can conclude the reasons why some participants have shown that they feel anxious and embarrassed when making mistakes and that they do not use the language confidently.

Although, most of the participants have admitted the importance of the English language in their lives but, they have shown that they do not communicate in English with their peers in the classroom or outside the classroom. Moreover, the results have shown that some of the students face difficulties in speaking English although some of them have agreed that teachers encourage them to talk freely in the classroom and the syllabus includes several tasks for speaking and several questions for oral communication. Most of the participants have agreed that teachers use the discussion method in the class and most of the teachers prepare activities for interacting with peers. Also, the participants agreed that the task of group work encourages them to use English and that they do some exercises in group work in the class, but the results have shown that around half of the students do not use the language in the classroom or outside the classroom.

The findings of the study have also shown that some students think that there should be an oral speaking test which (as several studies shown) helps to solve the problem of weakness in communication skills. Most of the participants have agreed that the syllabus concentrates on different skills of the language, but more than half of them agreed that there is a great concentration on grammar in EFL

$$
\text { مجلة كلية التربية- جامعة عين شمس } 50 \text { () العدد الأربعون (الجزء الرابع) } 2016
$$


(Jawaher Alrowayeh)

classroom. Concentrating on grammar in EFL class will lead to a lack in oral communication with the teacher and then that will affect the speaking skill negatively as concluded by many studies.

\section{Conclusion \& Recommendations}

The present study has analyzed the factors that affect oral communication in EFL classroom. A questionnaire was administered to students from the Higher Institute for Telecommunication and Navigation in Kuwait. The results of the study have shown several factors related to teachers, students, the syllabus and the teaching methods as mentioned above.

Based on what has been concluded in this study, the researcher recommends the following points:

- EFL teachers should be aware of their students' needs in order to use the communication strategies.

- Teachers should set a friendly atmosphere by disregarding their student's errors to avoid anxiety and embarrassment.

- Teachers should set a supportive atmosphere which will encourage their students to communicate freely in English.

- Teachers should train their learners to practice and use the different strategies to avoid difficult communication situations.

- Teachers should apply different teaching methods to help students communicate in English.

- Teachers should use both speaking and listening tests after drilling students on different types of listening and speaking exercises.

- Teachers should not emphasis on grammar in the class in order not to affect students' accuracy and fluency level in English.

العدد الواحد والأربعون (الجزء الاول) 2017

مجلة كلية التربية- جامعة عين شمس 51 () 
Factors Affecting Oral Communication In the EFL Classroom in Kuwait A Study

in the Higher Institute of Telecommunication and Navigation (HITN) in Kuwait

\section{References}

Abebe, D, Demis, G \& Deneke, T. (2014). Causes of students' limited participation in EFL classroom: Ethiopian public universities in focus. International Journal of Educational Research and Technology,6 (1). March 2015:pp.74-89.

Andre, V. (2003). The influence of affective variables on EFL/ ESL learning and teaching. The Journal of Imagination in Language Learning and Teaching. 7, pp. 92-97.

Batiha, J, Noor, N \& Mustafa, R. (2014). Exploring the factors of classroom anxiety in the context of EFL Arab students. International Journal of Social Science and Humanities Research, 2, (2), pp.18-31. April 2014-June 2014.

Bizzell, P. (1989). Review of the book " The Social construction of Written Communication." College Composition and Communication 40, pp. 483-486.

Campos, J. (2013). How to help EFL beginner students to communicate fluently. Revista de Lenguas Modernas, N 20, 2014/ 453-465 / ISSN; 1659-1933.

Faliva, M. (2012). Elements of optimizing the communication in EFL classes. The Round Table. Partium Journal of English Studies. ISSN 1844-2021.

Gilakjani, A. (2012). A study of factors affecting EFL learners' English pronunciation learning and the strategies for instruction. International Journal of Humanities and Social Science. 2, (3), February. pp.119-128. 2012.

Halliday, M.K. (1978). Language as a social semiotic. Edward Arnold, London.

Kang, S.J. (2005). Dynamic emergence of situational willingness to communicate: A comparison of behavior in whole class, group and dyadic interaction. System,34:pp. 480-493.

Kuutila, N.(2014). Teachers' effect on learners' willingness to communicate in L2. https://prezi.com.

Lisa, L.(2006). The relationship among teachers' verbal and nonverbal immediacy behaviors and students' willingness to speak in English in central Taiwanese college classrooms.

$$
\text { مجلة كلية التربية- جامعة عين شمس } 52 \text { () العدد الأربعون (الجزء الرابع) } 2016
$$


(Jawaher Alrowayeh)

Unpublished doctoral dissertation, Oral Roberts University, Tulsa, Oklahoma.

Mazouzi, S. (2013). Analysis of some factors affecting learners' oral performance. http://dspace.univ-biskra.dz.

Nazari, A \& Allahyar, N. (2012). Increasing willingness to communicate among English as a foreign language EFL students: Effective teaching strategies. Investigation In University Teaching and Learning, 8, summer 2012. ISSN 1740-5106.

Nishimura, K. (2000). Effective ways of communicative instruction in the Japanese EFL classroom: Balancing fluency and accuracy. http://www.eric.ed.gov.

Rahman, M. (2010). Teaching oral communication skills: A taskbased approach. ESP World, issue 1(27), volume 9, 2010 pp1-11.

Renandya, W \& Richards, J. (2002). Methodology in language teaching : An anthology of current practice. United States of America: Cambridge University Press.

Riasati, M. (2012). EFL learners' perceptions of factors influencing willingness to speak English in language classroom: A qualitative study. World Applied Science Journal, 17, (10): pp.1287-1297,2012.

Richards, J. \& Rodgers, T. (1986). Approaches and methods in language teaching: A description and analysis. Cambridge: Cambridge University Press.

Rodriguez, C \& Barrera. J. (2015). Oral communication and interaction. Ways to use in the EFL class. http://repository.uniminato.edu.

Savignon, S \& Wang, C. (2003). Communicative language teaching in EFL context: Learner attitudes and perceptions. IRAL 41 (2003), pp.223-249.

Shumin, K. (1997). Factors to consider: Developing adult EFL student's speaking abilities. Forum, 35, (3), pp.8.

Suresh, K. (2003). Theories of communication. Journalism and Communication, chapter (2). http:www.peoi.org.

Thornbury, S. (2005). How to teach speaking. Harmer, J.(Ed). London: Longman.

$$
\text { مجلة كلية التربية- جامعة عين شمس } 53 \text { () العدد الواحد والأربعون (الجزء الاول) } 2017
$$


Factors Affecting Oral Communication In the EFL Classroom in Kuwait A Study in the Higher Institute of Telecommunication and Navigation (HITN) in Kuwait

Tsui, A. (1996). Reticence and anxiety in second language learning. In K. Bailey \& d. Nunan (EDs.), Voices from the language classroom: Qualitative Research in Second Language Education (pp.145-167). Cambridge: Cambridge University Press. 